\title{
Refractory Primary Diffuse Large B-Cell Lymphoma of the Central Nervous System
}

National Cancer Institute

\section{Source}

National Cancer Institute. Refractory Primary Diffuse Large B-Cell Lymphoma of the

Central Nervous System. NCI Thesaurus. Code C157074.

Primary diffuse large B-cell lymphoma of the central nervous system that does not respond to treatment. 